Огляди літератури, оригінальні дослідження, погляд на проблему, випадок з практики, короткі повідомлення УДК 616.681-056.716-02:616.441-008.64]-018:547.96-092.9

DOI 10.11603/1811-2471.2019.v.i3.10393

\title{
ВПЛИВ ЕКСПЕРИМЕНТАЛЬНОГО ГІПЕРТИРЕОЗУ МАТЕРИНСЬКОГО ОРГАНІЗМУ НА ПОСТНАТАЛЬНИЙ МОРФОГЕНЕЗ ЯЄЧОК ПОТОМСТВА ЗА ДАНИМИ МОРФОМЕТРІЇ ТА ЛЕКТИНОВОÏ ГІСТОХІMIÏ
}

\author{
○А. Ю. Шегедін, Х. І. Струс, А. М. Ященко \\ Львівський національний медичний університет імені, Данила Галицького
}

РЕЗЮмЕ. 3 використанням методів морфометрії та лектинової гістохімії проведено дослідження впливу експериментального гіпертиреозу материнського організму на структурні компоненти яєчок потомства на послідовних етапах постнатального онтогенезу.

Мета - виявлення впливу гіпертиреозу материнського організму на мікроморфологію і глікановий профіль яєчок потомства.

Матеріал і методи. Гіпертиреоз індукували шляхом щоденного згодовування тваринам L-тироксину в дозі 100 мкг/кг протягом двох тижнів до покриття самок, упродовж усього гестаційного періоду та лактації. Панель лектинів включала GNA, PNA, SBA, WGA, SNA та LABA.

Результати. Встановили, що під впливом гіпертиреозу материнського організму в яєчках потомства на 20 пренатальну та 1 постнатальну добу зменшується вміст інтерстиціальної сполучної тканини, у складі сім'яних тяжів підвищується проліферативна активність клітин Сертолі. На 20 постнатальну добу виявлено підвищену проліферативну активність сперматогенного епітелію сім'яних трубочок у поєднанні з редукцією рецепторів лектинів у сперматоцитах адлюменального компартменту останніх. На 40 постнатальну добу в тварин дослідної групи виявлено прискорення біогенезу акросом, деструктивні зміни клітинних елементів зі зменшенням діаметра сім'яних трубочок та відповідним розширенням простору інтерстицію. Відмінності морфометричних параметрів та характеру взаємодії лектинів зі структурними компонентами яєчок щурів контрольної і дослідної груп були максимально виражені на 20 добу пренатального онтогенезу і нівелювались у статевозрілих тварин, що свідчить про транзиторний вплив материнського гіпертиреозу на гістофізіологію яєчок потомства. За умов материнського гіпертиреозу мала місце тенденція до редукції рецепторів лектинів у структурних компонентах яєчок потомства, однак достовірних якісних відмінностей у структурі їхніх вуглеводних детермінант не виявлено. У проведеному дослідженні лектини GNA та LABA інтенсивно взаємодіяли з фетальними клітинами Лейдіга, PNA, SBA та SNA - з акросомними гранулами та шапочками ранніх сперматид, WGA та PNA - з макрофагами у складі інтерстицію яєчка, що дозволяє рекомендувати ці лектини в якості селективних гістохімічних маркерів означених клітинних популяцій.

Висновки. Отримані дані поглиблюють сучасні уявлення стосовно негативного впливу гіпертиреозу материнського організму на морфогенез та гістофізіологію яєчок потомства, а також демонструють нові можливості використання лектинів в якості селективних гістохімічних маркерів структурних компонентів яєчок щура.

КЛючОВІ СЛОВА: щури; гіпертиреоз материнського організму; морфогенез яєчок потомства; морфометрія; лектинова гістохімія.

Вступ. Непліддя є актуальною медичною та соціальною проблемою, оскільки, за даними статистики, неплідними є близько 20 \% шлюбів, причому у 50 \% випадків його причиною є чоловічий фактор [1]. Донедавна вважали що прямого зв'язку між функцією щитоподібної залози та гістофізіологією яєчок не існує, однак новітні дослідження продемонстрували тісну залежність чоловічих статевих залоз від впливу тиреоїдних гормонів - тироксину та трийодотироніну [2-5]. Свою дію ці гормони реалізують за посередництва вмонтованих в ядерну оболонку тиреоїдних рецепторів, серед яких розрізняють ізоформи TRa1, TRa2, TRß1, TRß2, здатні еухроматинізувати ядерну ДНК, обумовлюючи цим транскрипцію численних генів, котрі кодують різноманітні білки, наслідком чого $\epsilon$ підвищення метаболізму клітин. За умов дефіциту тиреоїдних гормонів чутливі до них ділянки ДНК перебувають у гетехроматинізованому стані, що обумовлює пригнічення метабо- лізму [6]. Окрім вищезгаданого механізму, тироксин і трийодотиронін здатні впливати на обмін речовин у клітині, оминаючи ії геном, оскільки рецептори цих гормонів знайдені у складі плазматичної та мітохондріальної мембран, а також у цитоплазмі [7].

Вплив на чоловічі статеві залози тиреоїдні гормони здійснюють як шляхом безпосередньої взаємодії зі сперматогенними клітинами, так і опосередковано через клітини Сертолі і Лейдіга, оскільки у всіх трьох клітинних популяціях виявлені рецептори тироксину $[5,8,9]$. Як гіпо-, так i гіпертиреоз обумовлюють порушення процесів сперматогенезу, зменшення кількісних характеристик і рухливості сперматозоїдів, індукують апоптоз сперматогоній; у перинатальному періоді онтогенезу і дитячому віці згадані ендокринопатії можуть призводити до незворотних змін у яєчку і бути етіологічними чинниками чоловічої неплідності [10-12]. Враховуючи вищезазначене, 
Огляди літератури, оригінальні дослідження, погляд на проблему, випадок з практики, короткі повідомлення вивчення впливу дисбалансу тиреоїдних гормонів материнського організму на постнатальний розвиток чоловічих статевих залоз потомства слід вважати актуальним завданням.

Численні публікації свідчать про важливу роль вуглеводних детермінант глікокон'югатів рецепторів лектинів - у гістофізіології як нормальних структур організму, так і при розвитку різноманітних форм патології [12-16]. У попередніх роботах [17-20] ми охарактеризували морфологічні параметри і глікановий профіль яєчка потомства щурів, що розвивалися за фізіологічних умов та на тлі гіпотиреозу материнського організму. Встановлено закономірності перерозподілу вуглеводних детермінант, перебудови мікроморфології структурних компонентів яєчка, можливості використання лектинів як специфічних маркерів окремих типів його клітинних популяцій.

Мета - вивчення впливу гіпертиреозу материнського організму на мікроморфологію і глікановий профіль яєчок потомства, а також встановлення можливостей використання лектинів як селективних гістохімічних маркерів структур яєчка при означеній патології.

Матеріал і методи дослідження. Дослід проводили на 25 самках лінії Вістар масою 180-200 г, які були поділені на дві групи: перша - контрольна (10 тварин), друга - дослідна (15 тварин); у контрольній групі завагітніли 5 самок, від яких було отримано потомство в кількості 41 тварини; у групі з індукованим гіпертиреозом завагітніли також 5 тварин, потомство яких склало 40 щурят. Тварин утримували у стандартних умовах віварію з дотриманням санітарно-гігієнічних норм та раціону харчування. Дослідження на тваринах проводили за погодженням з Комісією з біоетики ЛНМУ (протокол № 2 від 15.02.2016р.) відповідно до положень Європейської конвенції щодо захисту хребетних тварин, яких використовують в експериментальних та інших наукових цілях (Страсбург, 1986 р.), Директиви Ради Європи 2010/63/EU, Закону України № 3447-IV «Про захист тварин від жорстокого поводження».

Екзогенний гіпертиреоз індукували згодовуванням тваринам експериментальної групи L-тироксину (Berlin-Chemie, Німеччина) з розрахунку 100 мкг/кг маси тіла. Тироксин додавали в їжу щоденно протягом двох тижнів до покриття самок, упродовж усього гестаційного періоду та лактації. Після другого тижня від початку експерименту шляхом щоденного взяття мазків з піхви самок контролювали естральний цикл. Самок в стадії еструсу підсаджували до інтактних самців. Перший день вагітності ідентифікували за наявністю сперматозоїдів у піхвових мазках.

Контроль функції щитоподібної залози здійснювали радіологічним методом шляхом визначення гормонів $\mathrm{T}_{3}$ та $\mathrm{T}_{4}$ у сироватці крові за допомогою стандартних наборів у радіоізотопній лабораторії Львівської обласної клінічної лікарні. Досягнення стану гіпертиреозу верифікували дослідженням щитоподібних залоз самок: макроскопічно залози були менших розмірів, порівняно з контролем, бліді, атрофовані; мікроскопічно виявлялися великі фолікули зі щільним колоїдом та низьким вмістом тироцитів.

З моменту датованої вагітності забирали яєчка у потомства дослідних та контрольних самок на 20-у пренатальну, 1-у, 20-у, 40-у та 120-у добу постнатального розвитку. Гістологічний матеріал фіксували у розчині Буена, з наступним зневодненням, ущільненням і заливкою у парафін. Для вивчення загальної морфології зрізи товщиною 5-7 мкм зафарбовували гематоксиліном та еозином. Морфометричні дослідження включали підрахунок кількості сім'яних тяжів (СТ) та сім'яних трубочок (СТр) в одному полі зору, визначення їхнього діаметра та площі, індексу сперматогенезу, кількості клітин Лейдіга в полі зору [1, 21, 22]. До уваги брали лише поперечно зрізані сім'яні тяжі та сім'яні трубочки, які мали округлу форму. Індекс сперматогенезу визначали за формулою I:

$$
C=\Sigma A: N,
$$

де $A$-кількість шарів сперматогенних клітин у сім'яних трубочках, $N$ - число проаналізованих сім'яних трубочок.

Вуглеводні детермінанти структур яєчка ідентифікували з використанням лектину підсніжника (GNA, специфічний до DMan), арахісу (PNA, специфічний до DGalß(1-3)DGalNAc), сої (SBA, специфічний до DGalNAc), зародків пшениці (WGA, специфічний до DGlcNAc > NeuNAc), бузини чорної (SNA, NeuNAca(2-6)DGal), золотого дощу (LABA, LFuc). Усі використані лектини, за винятком лектину арахісу, були очищені і кон'юговані з пероксидазою доктором фармацевтичних наук професором В. Антонюком; лектин арахісу виробництва фірми Sigma. Візуалізацію рецепторів лектинів здійснювали 3,3'-діамінобензидином (Sigma, США) в присутності $\mathrm{H}_{2} \mathrm{O}_{2}$, як описано раніше [19].

Для характеристики мікроморфології яєчка щура на послідовних етапах постнатального онтогенезу було використано атлас Parker et al. [23], стадії спермогенезу ідентифікували за шкалою Leblond et al. [24]. Мікроскопію та фотографування препаратів здійснювали з використанням мікроскопа "Granum R6053», обладнаного фотокамерою «Echoo-Imager 502000», та комп'ютерної програми «ToupView 3.7». Морфометричні дослідження проводили з використанням комп'ютерної програми UTHSCSA «Image Tool for Windows. 
Огляди літератури, оригінальні дослідження, погляд на проблему, випадок з практики, короткі повідомлення Version 2.00». Статистичну обробку даних здійснювали за допомогою комп'ютерної програми «Місrosoft Office Excell 2003» та «Statistica 6.0» з визначенням «М» та середньої похибки «т». У роботі використані три рівні достовірності: $p<0,05$; $p<0,01 ; p<0,001$ [25].

Результати й обговорення. Гіпертиреозний стан дещо зменшував фертильність самок. Із задіяних в експерименті 15 тварин завагітніло 5, тоді як у контрольній групі з 10 тварин завагітніло також 5. Середня кількість щурят від самки з групи екзогенного гіпертиреозу складала 8,0 тварин проти 8,2 щурят від самки контрольної групи, тоді як на тлі гіпотирозу пригнічення фертильності було значно вагоміше: індекс народжуваності склав 6,4 щурят від однією самки, 6 \% плодів були мертвонародженими.

Середня маса тіла потомства, що розвивалося за умов експериментального гіпертиреозу материнського організму, на 20 пренатальну добу становила $(5,72 \pm 0,24)$ г (у контрольній групі $(2,91 \pm 0,14)$ г), що свідчило про істотний стимуляційний вплив тироксину на процеси анаболізму і росту плодів. На 1 постнатальну добу маса новонароджених щурят гіпертиреозної групи $((6,19 \pm 0,18)$ г) наближалась до показників контрольної групи тварин $((5,84 \pm 0,11)$ г).

На 10 постнатальну добу маса щурят в умовах експерименту становила $(14,83 \pm 0,61)$ г, тоді як у контрольній групі цей показник склав $(17,06 \pm 0,15)$ г $(p<0,01)$. До 40 постнатальної доби різниця між масою тіла потомства дослідної і контрольної груп стала ще вагомішою - $(43,96 \pm 1,27)$ г за умов досліду проти $(50,37 \pm 1,65)$ г у групі контролю $(p<0,01)$, що, очевидно, обумовлено переважанням катаболічних процесів, які розвивалися під впливом материнського гіпертиреозу. Підвищення катаболізму екстраполювалося на зміну мікроморфології яєчок. Наші спостереження загалом узгоджуються з тенденціями щодо впливу дисбалансу тиреоїдних гормонів материнського організму на фертильність та зміни маси плодів, задокументованих у праці Kumar et al. [26].

Результати морфометричних досліджень наведено у таблиці 1.

Таблиця 1. Результати проведених морфометричних досліджень

\begin{tabular}{|c|c|c|c|c|c|c|}
\hline \multirow{2}{*}{\multicolumn{2}{|c|}{$\begin{array}{l}\text { Термін } \\
\text { розвитку }\end{array}$}} & \multicolumn{3}{|c|}{ Сім'яні тяжі (СТ) / Сім'яні трубочки (СТр) } & \multirow[b]{2}{*}{$\begin{array}{c}\text { індекс } \\
\text { сперматогенезу }\end{array}$} & \multirow[b]{2}{*}{$\begin{array}{c}\text { К-сть клітин } \\
\text { Лейдіга в полі } \\
\text { зору }\end{array}$} \\
\hline & & 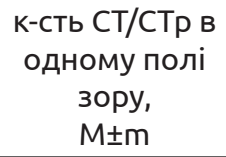 & 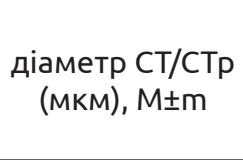 & $\begin{array}{c}\text { площа СТ/CTр } \\
\left(\mathrm{MKM}^{2}\right), \mathrm{M} \pm \mathrm{m}\end{array}$ & & \\
\hline \multirow{2}{*}{$\begin{array}{l}20 \text { пренатальна } \\
\text { доба }\end{array}$} & K & $57,67 \pm 3,38$ & $52,65 \pm 1,09$ & $2183,74 \pm 89,61$ & - & $26,50 \pm 6,03$ \\
\hline & $T$ & $84,60 \pm 5,19 * * *$ & $53,83 \pm 0,88$ & $2279,77 \pm 74,48$ & - & $43,00 \pm 1,48^{*}$ \\
\hline \multirow{2}{*}{$\begin{array}{l}1 \text { постнатальна } \\
\text { доба }\end{array}$} & K & $129,60 \pm 2,94$ & $56,52 \pm 1,26$ & $2517,91 \pm 110,35$ & - & $14,00 \pm 4,15$ \\
\hline & $T$ & $139,67 \pm 4,41$ ** & $46,77 \pm 1,06^{* * *}$ & $1724,07 \pm 79,65^{* * *}$ & - & $8,33 \pm 0,56$ \\
\hline \multirow{2}{*}{$\begin{array}{l}20 \text { постнатальна } \\
\text { доба }\end{array}$} & K & $89,40 \pm 8,94$ & $86,21 \pm 1,67$ & $5852,06 \pm 228,75$ & $2,78 \pm 0,22$ & $11,33 \pm 0,92$ \\
\hline & $\mathrm{T}$ & $97,00 \pm 3,49$ & $106,71 \pm 2,59 * * *$ & $8980,47 \pm 442,63 * * *$ & $3,26 \pm 0,24 *$ & $10,83 \pm 0,60$ \\
\hline \multirow{2}{*}{$\begin{array}{l}40 \text { постнатальна } \\
\text { доба }\end{array}$} & K & $23,67 \pm 3,60$ & $193,17 \pm 8,96$ & $29795,94 \pm 2663,63$ & $4,45 \pm 0,34$ & $8,83 \pm 3,61$ \\
\hline & $T$ & $27,33 \pm 1,51$ & $166,05 \pm 6,89 *$ & $21942,10 \pm 1855,60 *$ & $5,22 \pm 0,32$ & $9,00 \pm 0,85$ \\
\hline \multirow{2}{*}{$\begin{array}{l}120 \text { постнатальна } \\
\text { доба }\end{array}$} & $K$ & $11,33 \pm 0,41$ & $253,61 \pm 2,01$ & $50514,30 \pm 804,83$ & $3,78 \pm 0,28$ & $7,50 \pm 1,45$ \\
\hline & $T$ & $10,67 \pm 0,41$ & $253,69 \pm 2,11$ & $50551,25 \pm 849,18$ & $4,11 \pm 0,35$ & $9,33 \pm 0,99$ \\
\hline
\end{tabular}

Примітки: 1. К - контроль; Т - група гіпертиреозу; підрахунок кількісних показників першої колонки здійснювали при збільшенні мікроскопа ×140, інших показників - при $\times 560$;

2. Рівні достовірності: * $p<0,05 ;{ }^{* *} p<0,01 ;{ }^{* * *} p<0,001$.

Як видно із наведеної таблиці, на 20 добу пренатального онтогенезу на тлі гіпертиреозу розвивалося ущільнене пакування СТ (рис. 1А, Б): унаслідок редукції простору інтерстицію при практично однаковому діаметрі СТ у групах контролю і досліду в одному полі зору препаратів, отриманих від тварин експериментальної групи, поміщалося $(84,60 \pm 5,19) \mathrm{CT}$, тоді як у контрольній групі цей показник становив $(57,67 \pm 3,38)$ CТ $(p<0,001)$. На наш погляд, описаний феномен $\epsilon$ наслідком тироксин-індукованого посилення проліферації клітин Сертолі, які, згідно з даними Рarker et al. [23], у перинатальному періоді морфогенезу яєчка складають периферію СТ.

Іншою характерною рисою експериментальних тварин цієї вікової групи було достовірне збільшення кількості фетальних клітин Лейдіга, що свідчить про індукування тироксином їхньої проліферативної активності. У процесі вікової прогресії число СТ/СТр у одному полі зору (вміст інтерстиційної сполучної тканини), як і вміст клітин Лейдіга у ній, поступово нормалізувалися. Наші 
Огляди літератури, оригінальні дослідження, погляд на проблему, випадок з практики, короткі повідомлення
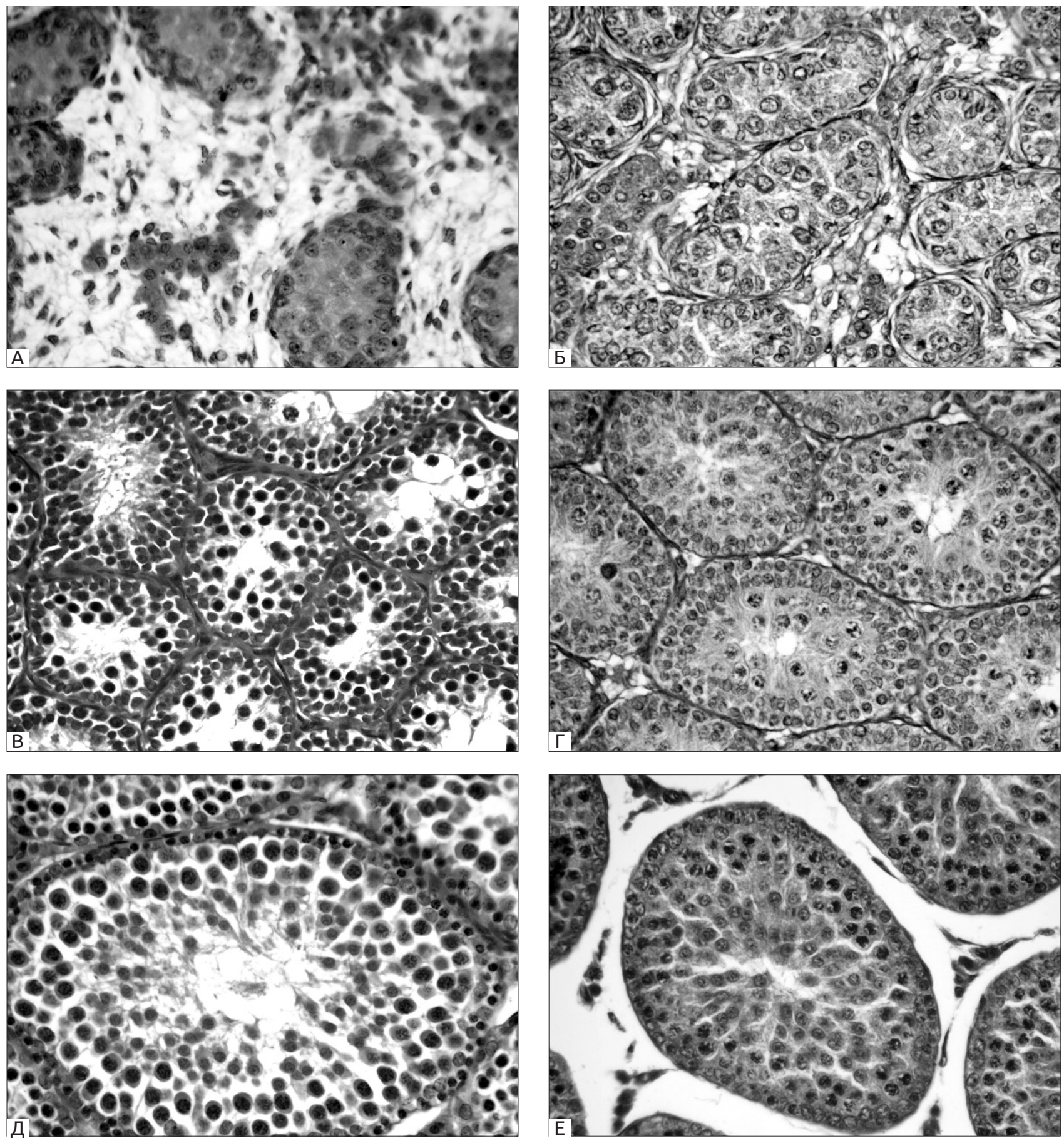

Рис. 1. Мікроморфологія яєчок щурів на 20-у добу пренатального (А, Б), 20-у (В, Г) та 40-у (Д, Е) доби постнатального онтогенезу. А, В, Д-контроль, Б, Г, Е- дослід. Забарвлення гематоксиліном та еозином. 36.×560.

спостереження дещо відрізняються від даних огляду Wagner et al. [5], котрі засвідчили дотермінове завершення проліферації клітин Сертолі у поєднанні $з$ їх прискореним дозріванням під впливом надлишку тиреоїдних гормонів, що обумовлювало дотермінову каналізацію СТр і мало негативний вплив на процеси сперматогенезу.

На 1 постнатальну добу на тлі гіпертиреозу задокументовано помірне зменшення діаметра i площі СТ, яке на 20 постнатальну добу змінювалося достовірним розширенням СТр (рис. 1В, Г), що, очевидно, обумовлено опусканням яєчок у калитку на 16-18 добу постнатального онтогенезу [23]. Відтак на 40 постнатальну добу діаметр СТр достовірно зменшувався, з подальшою нормалізацією у дорослих щурів. Зростання індексу сперматогенезу під впливом надлишку тироксину, правдоподібно, поєднувалося зі зниженням якісних характе- 
Огляди літератури, оригінальні дослідження, погляд на проблему, випадок з практики, короткі повідомлення ристик сформованих сперматозоїдів. На 40 постнатальну добу дегенеративні зміни і апоптоз сперматогенних клітин обумовлювали редукцію розміру СТр, що створювало передумови для компенсаторного розширення простору, заповненого інтерстиційною сполучною тканиною (рис. 1Д, Е).

У наших попередніх дослідженнях [17-19] було показано можливість маркування фетальних клітин Лейдіга лектинами GNA, PSA, Con A та LABA, а також макрофагів інтерстицію - лектином WGA. На тлі гіпертиреозу селективність маркування збереглася (рис. 2А, Б). На 20 постнатальну добу спер-

матоцити в адлюменальному компартменті значної частини СТр тварин контрольної групи експонували цитоплазматичні глікокон'югати, що виявляли спорідненість до переважної більшості використаних у роботі лектинів, тоді як в умовах експерименту така взаємодія була значною мірою редукована або цілковито відсутня. Означену різницю можна віднести як на рахунок індукованого гіпертиреозом пригнічення процесингу глікополімерів, так і похибки використаного методу лектинової гістохімії, який більшою мірою характеризує якісні, а не кількісні параметри глікому.
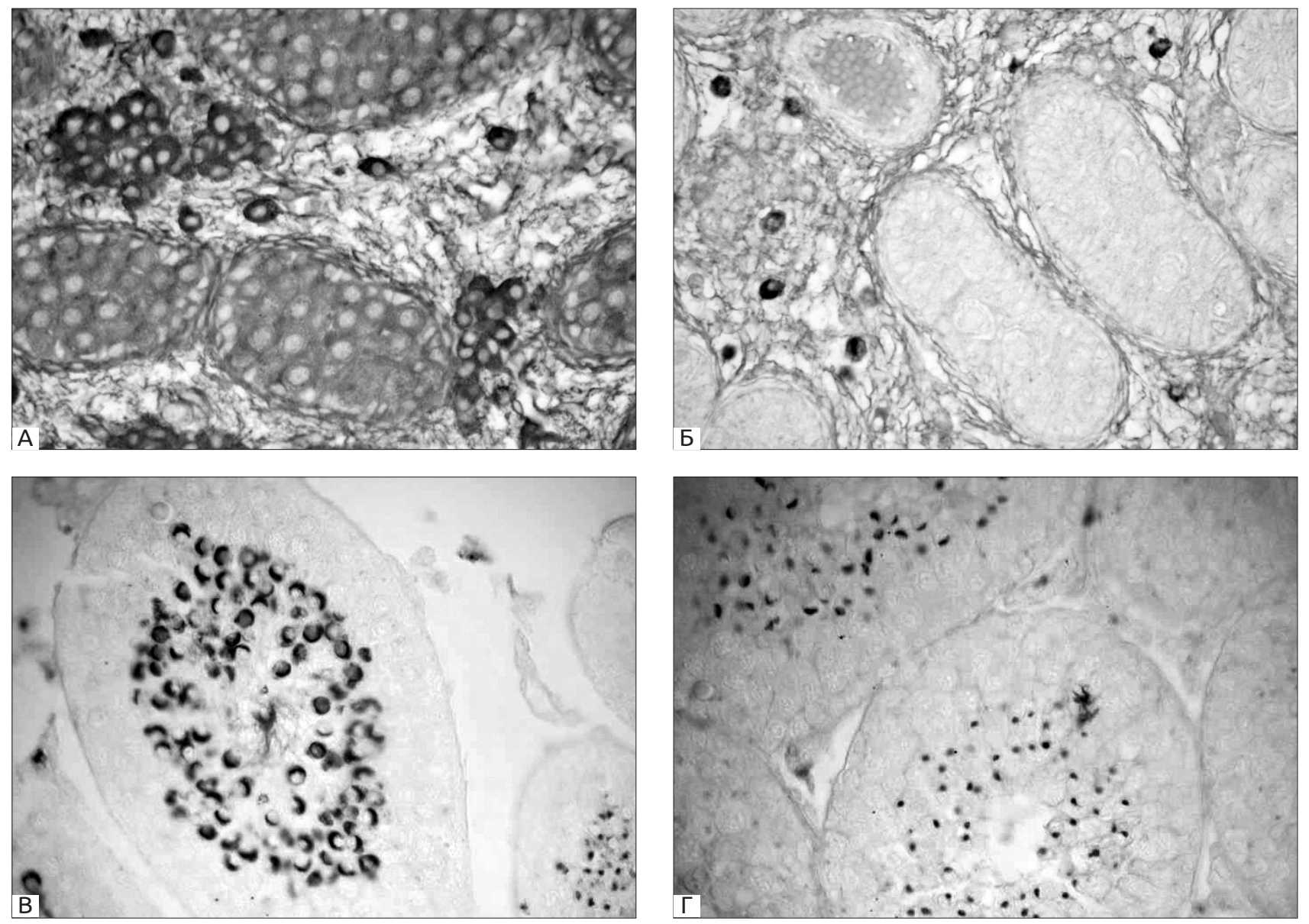

Рис. 2. Приклади селективного маркування структурних елементів яєчок потомства, що розвивалося за умов гіпертиреозу материнського організму. А - фетальні клітини Лейдіга, 20-а доба пренатального розвитку, обробка лектином GNA; Б-макрофаги у складі інтерстицію, 1-а постнатальна доба, обробка лектином WGA; B, Г- акросомні гранули та шапочки, виявлені з використанням лектинів PNA (В) та SNA (Г), 40-а постнатальна доба. 36.×560.

На 40 постнатальну добу лектини PNA та SNA інтенсивно маркували численні акросомні гранули і шапочки сперматид тварин, що розвивалися за умов материнського гіпертиреозу (рис. 2B, Г), тоді як у пробах яєчок тварин цієї ж вікової категорії у групі контролю елементи акросомної системи були розвинені значно слабше; аналогічного ступеня розвитку вони досяга- ли у старшій віковій групі (в умовах нашого експерименту - у дорослих щурів). Подібна підвищена реактивність акросомних шапочок ранніх сперматид була ідентифікована на 40 постнатальну добу в дослідній групі з лектином SBA; у зразках, отриманих від контрольних тварин така реактивність була відсутня. Ці спостереження свідчать про гіпертиреоз-індуковане прискорен- 
Огляди літератури, оригінальні дослідження, погляд на ня процесів біогенезу акросом, що вкладається у загальну концепцію прискорення морфогенезу яєчок під впливом надлишку тиреоїдних гормонів $[5,8]$.

Клітинні елементи СТр яєчок дорослих щурів виявляли значну гетерогенність у взаємодії з лектинами, що, очевидно, пов'язано з їхнім перебуванням у різних фазах сперматогенного циклу, а не з впливом гіпертиреозу. Всі використані в роботі лектини продемонстрували у яєчках експериментальної групи на 40 постнатальну добу та у дорослих тварин розширення інтерстиційних просторів на зміну дефіциту інтерстицію, характерного для перинатального періоду онтогенезу.

Висновки. 1. Отримані результати свідчать про негативний вплив гіпертиреозу материнського організму на морфогенез та гістофізіологію яєчок потомства, хоча його наслідки, порівняно з гіпотирозом, мали слабший деструктивний потенціал. На 20 пренатальну та 1 постнатальну добу вплив гіпертиреозу проявлявся підвищенням проліферативної активності клітин Сертолі у складі сім'яних тяжів, зменшенням об'єму інтерстицію, редукцією вуглеводних детермінант (рецепторів лектинів) в усіх структурних компонентах яєчка. На 20 постнатальну добу виявлено підвищену проліферативну активність сперматогенного епітелію, у поєднанні з редукцією рецепторів лектинів у сперматоцитах адлюменального компартменту. На 40 роблему, випадок з практики, короткі повідомлення постнатальну добу у тварин дослідної групи виявлено прискорення біогенезу акросом.

2. Відмінності у зв'язуванні лектинів зі структурними компонентами яєчок щурів контрольної і дослідної груп були максимально виражені на 20 добу пренатального онтогенезу і практично нівелювались у статевозрілих тварин, що свідчить про транзиторний вплив материнського гіпертиреозу на гістофізіологію яєчок потомства. За умов материнського гіпертиреозу була наявна тенденція до редукції рецепторів лектинів у структурних компонентах яєчок потомства, однак достовірних якісних відмінностей у структурі їхніх вуглеводних детермінант не виявлено. У проведеному дослідженні лектини GNA та LABA інтенсивно взаємодіяли з фетальними клітинами Лейдіга, лектини PNA, SBA та SNA - з акросомними гранулами та шапочками ранніх сперматид, клиноподібними акросомами сперматозоїдів, лектини WGA та PNA з макрофагами у складі інтерстицію яєчка, що дозволяє рекомендувати ці лектини в якості селективних гістохімічних маркерів означених клітинних популяцій.

Перспективи подальших досліджень. У подальших дослідженнях планується вивчення вуглеводних детермінант структурних компонентів яєчка щурів в процесі онтогенезу з використанням більш широкої панелі набору лектинів різної вуглеводної специфічності.

\section{ЛІТЕРАТУРА}

1. Гісто- та ультраструктурні зміни в яєчку щурів 3 хронічною алкогольною інтоксикацією / Б. В. Грицуляк, В. Б. Грицуляк, М. Б. Пастух, Н. П. Долинко // Світ медицини та біології. - 2014. - № 2 (44). - Р. 114-117.

2. Developmental expression of thyroid hormone receptors in the rat testis / J. J. Buzzard, J. R. Morrison, M. K. O’Bryan, Q. Song // Biol. Reprod. - 2000. - Vol. 62 (3). P. 664-669.

3. Krajewska-Kulak E. Thyroid function in male infertility / E. Krajewska-Kulak, P. Sengupta // Front Endocrinol. 2013. - Vol. 4. - P. 174. DOI: 10.3389/Fendo.2013.00174.

4. Singh R. Thyroid hormones in male reproduction and fertility / R. Singh, A. J. Hamada, A. Agarwal // The Open Reproductive Science Journal. - 2011. - Vol. 3. - P. 98-104.

5. Wagner M. S. The role of thyroid hormone in testicular development and function / M. S. Wagner, S. M. Wajner, A. L. Maia // J. Endocrinol. - 2008. - Vol. 199. - P. 351365. DOI: 10.1677/JOE-08-0218.

6. Boelaert K. Thyroid hormones in health and disease / K. Boelaert, J. A. Franklyn // J. Endocrinol. - 2005. - Vol. 187. P. 1-15.

7. Davis P. J. Nongenomic actions of thyroid hormone / P. J. Davis, F. Goglia, J. L. Leonard // Nature Rev. Endocrinol. - 2016. - Vol. 12 (2). - P. 111-121.
8. Wagner M. S. Is there a role for thyroid hormone on spermatogenesis? / M. S. Wagner, S. M. Wajner, A. L. Maia // Microsc. Res. Tech. - 2009. - Vol. 72 (11). - P. 796-808.

9. Auharek S. A. Postnatal testis development, Sertoli cell proliferation and number of different spermatogonial types in C57BL/6J mouse made transiently hypo- and hyperthyroidic during the neonatal period / S. A. Auharek, L. R. de Franka // J. Anat. - 2010. - Vol. 216. - P. 577-588.

10. Impact of thyroid disease on testicular function / S. LaVignera, R. Vita, R. A. Condorelli, L. M. Mongioi // Endocrine. - 2017. - Vol. 58 (3). - P. 397-407.

11. New insight for male infertility revealed by alterations in spermatic function and differential testicular expression of thyroid-related genes / R. M. Romano, S. N. Gomes, N. C. Cardoso, L. Schiessl // Endocrine. - 2017. - Vol. 55 (2). - Р. 607-617.

12. Луцик А. Д. Лектины в гистохимии / А. Д. Луцик, Е. С. Детюк, М. Д. Луцик. - Львов : Вища школа, 1989. $144 \mathrm{c}$.

13. Антонюк В. О. Лектини та їх сировинні джерела / В. О. Антонюк. - Львів : Кварт, 2005. - 550 с.

14. Sharon N. Lectins: carbohydrate-specific reagents and biological recognition molecules / N. Sharon // J. Biol. Chem. - 2007. - Vol. 282. - P. 2753-2764. 
Огляди літератури, оригінальні дослідження, поглядн

15. Roth J. Lectins for histochemical demonstration of glycans / J. Roth // Histochem Cell Biol. - 2011. Vol. 136. - P. 117-130.

16. Dan X. Development and applications of lectins as biological tools in biomedical research / X. Dan, W. Liu // Med Res Rev. - 2015. - Vol. 36. - P. 221-247.

17. Шегедін А. Ю. Експонування глікокон'югатів у постнатальному морфогенезі яєчка щура за даними PAS-реакції та лектинової гістохімії / А. Ю. Шегедін, А. М. Ященко, О. Д. Луцик // Світ медицини та біології. 2017. - Vol. 2 (60). - P. 174-178.

18. Shegedin A. Modification of rat testis carbohydrate determinants in postnatal morphogenesis as detected by lectin probes / A. Shegedin, A. Yashchenko, A. Lutsyk // J. Cell. Sci. Ther. - 2017. - Vol. 8. - P. 274. DOI: $10.4172 / 2157-7013.1000274$.

19. Шегедін А. Ю. Вплив гіпотирозу материнського організму на постнатальний морфогенез яєчок щурів за даними морфометрії та лектинової гістохімії / А. Ю. Шегедін, А. М. Ященко, О. Д. Луцик // Acta Medica Leopoliensia. - 2017. - Vol. 23 (3). - P. 85-93.

20. Шегедін А. Ю. Імуногістохімічне дослідження яєчок потомства щурів, що розвивалося за умов експериментального гіпотирозу материнського організму /

\section{REFERENCES}

1. Hrytsuliak, B.V., Hrytsuliak, V.B., Pastukh, M.B., \& Dolynko, N.P. (2014). Histo- ta ultrastrukturni zminy v yaiechku shchuriv z khronichnoiu alkoholnoiu intoksykatsiieiu [Histoand ultrastructural changes in the testis of rats with chronic alcohol intoxication]. Svit medytsyny ta biolohii - The World of Medicine and Biology, 2 (44), 114-117 [in Ukrainian].

2. Buzzard, J.J., Morrison, J.R., O’Bryan, M.K., \& Song, Q. (2000). Developmental expression of thyroid hormone receptors in the rat testis. Biol. Reprod., 62 (3), 664-669.

3. Krajewska-Kulak, E., \& Sengupta, P. (2013). Thyroid function in male infertility. Front. Endocrinol., 4, 174. DOI:10.3389/Fendo.2013.00174.

4. Singh, R., Hamada, A.J., \& Agarwal, A. (2011). Thyroid hormones in male reproduction and fertility. The Open Reproductive Science Journal, 3, 98-104.

5. Wagner, M.S., Wajner, S.M., \& Maia, A.L. (2008). The role of thyroid hormone in testicular development and function. J. Endocrinol., 199, 351-365. DOI: 10.1677/JOE08-0218.

6. Boelaert, K., \& Franklyn, J.A. (2005). Thyroid hormones in health and disease. J. Endocrinol., 187, 1-15.

7. Davis, P.J., Goglia, F., \& Leonard, J.L. (2016). Nongenomic actions of thyroid hormone. Nature Rev. Endocrinol., $12(2), 111-121$.

8. Wagner, M.S., Wajner, S.M., \& Maia, A.L. (2009). Is there a role for thyroid hormone on spermatogenesis? Microsc. Res. Tech., 72 (11), 796-808.

9. Auharek, S.A., \& de Franka, L.R. (2010). Postnatal testis development, Sertoli cell proliferation and number of different spermatogonial types in $\mathrm{C} 57 \mathrm{BL} / 6 \mathrm{~J}$ mouse made transiently hypo- and hyperthyroidic during the neonatal period. J. Anat., 216, 577-588. проблему, випадок з практики, короткі повідомлення А. Ю. Шегедін, Н. О. Амбарова, А. М. Ященко // Могрhоlogia. -2019.

21. Пастухова В. А. Морфологічне дослідження сперматогенезу статевозрілих щурів / В. А. Пастухова // Вісник проблем біології і медицини. - 2011. - Vol. 2 (88). Р. $145-146$.

22. Дуденкова Н. А. Изменения морфо-функционального состояния и продуктивности семенных желез белых крыс при воздействии ацетата свинца / Н. А. Дуденкова, О. С. Шубина // Фундаментальные исследования. - 2013. - Vol. 10 (6). - P. 1253-1259.

23. Atlas of histology of the juvenile rat / G. A. Parker, C. A. Picut eds. Amsterdam: Elsevier-Academic Press, 2016. P. 227-247.

24. Leblond C. P. Definition of the stages of the cycle of the seminiferous epithelium in the rat / C. P. Leblond, Y. Clermont // Ann NY Acad Sci. - 1952. - Vol. 55. P. 548-573.

25. Гумецький Р. Я. Математичні методи в біології / Р. Я. Гумецький, Б. М. Паляниця, М. Е. Чабан. - Львів : Вища школа, 2004. - 111 с.

26. Kumar R. Altered maternal thyroid function: fetal and neonatal development of rat / R. Kumar, B. N. Chaudhuri // Indian J. Physiol. Pharmacol. - 1989. - Vol. 33 (4). - P. 233-238.

10. LaVignera, S., Vita, R., Condorelli, R.A., \& Mongioi, L.M. (2017). Impact of thyroid disease on testicular function. Endocrine, 58 (3), 397-407.

11. Romano, R.M., Gomes, S.N., Cardoso, N.C., \& Schiessl, L. (2017). New insight for male infertility revealed by alterations in spermatic function and differential testicular expression of thyroid-related genes. Endocrine, 55 (2), 607-617.

12. Lutsik, A.D., Detyuk, Ye.S., \& Lutsik, M.D. (1989). Lektiny $v$ gistokhimii [Lectins in histochemistry]. Lviv: Vyshcha shkola [in Russian].

13. Antoniuk, V.O. (2005). Lektyny ta yikh syrovynni dzherela [Lectins and their raw materials]. Lviv: Kvart [in Ukrainian].

14. Sharon, N. (2007). Lectins: carbohydrate-specific reagents and biological recognition molecules. J. Biol. Chem., 282, 2753-2764.

15. Roth, J. (2011). Lectins for histochemical demonstration of glycans. Histochem. Cell Biol., 136, 117-130.

16. Dan, X., \& Liu, W. (2015). Development and applications of lectins as biological tools in biomedical research. Med. Res. Rev., 36, 221-247.

17. Shehedin, A.Yu., Yashchenko, A.M., \& Lutsyk, O.D. (2017). Eksponuvannia hlikokoniuhativ u postnatalnomu morfohenezi yaiechka shchura za danymy PAS-reaktsii ta lektynovoi histokhimii [Exposure of glycoconjugates in postnatal rat morphogenesis according to PAS response and lectin histochemistry]. Svit medytsyny ta biolohii - The World of Medicine and Biology, 2 (60), 174-178 [in Ukrainian].

18. Shegedin, A., Yashchenko, A., \& Lutsyk, A. (2017). Modification of rat testis carbohydrate determinants in postnatal morphogenesis as detected by lectin probes. J. Cell Sci. Ther. 8, 274. DOI 10.4172/2157-7013.1000274. 
Огляди літератури, оригінальні дослідження, погляд на проблему, випадок з практики, короткі повідомлення

19. Shehedin, A.Yu., Yashchenko, A.M., \& Lutsyk, O.D. (2017). Vplyv hipotyrozu materynskoho orhanizmu na postnatalnyi morfohenez yaiechok shchuriv za danymy morfometrii ta lektynovoi histokhimii [Influence of maternal body hypothyroidism on postnatal rat egg morphogenesis according to morphometry and lectin histochemistry]. Acta Medica Leopoliensia - Acta Medica Leopoliensia, 23 (3), 85-93 [in Ukrainian].

20. Shehedin, A.Yu., Ambarova, N.O., \& Yashchenko, A.M. (2019). Imunohistokhimichne doslidzhennia yaiechok potomstva shchuriv, shcho rozvyvalosia za umov eksperymentalnoho hipotyrozu materynskoho orhanizmu [Immunohistochemical study of testicular progeny of rats that developed under experimental maternal hypothyroidism.]. Morphologia.

21. Pastukhova, V.A. (2011). Morfolohichne doslidzhennia spermatohenezu statevozrilykh shchuriv [Morphological study of spermatogenesis of adult rats.]. Visnyk problem biolohii i medytsyny - Bulletin of Problems of Biology and Medicine, 2 (88), 145-146 [in Ukrainian].
22. Dudenkova, N.A., \& Shubina, O.S. (2013). Izmeneniya morfo-funktsionalnogo sostoyaniya i produktivnosti semennykh zhelez belykh krys pri vozdeystvii atsetata svintsa [Changes in the morphological and functional state and productivity of the seminal glands of white rats when exposed to lead acetate]. Fundamentalnyye issledovaniya Basic Research, 10 (6), 1253-1259 [in Russian].

23. Parker, G.A., \& Picut, C.A. (Eds.). (2016). Atlas of histology of the juvenile rat. Amsterdam: Elsevier-Academic Press.

24. Leblond, C.P., \& Clermont, Y. (1952). Definition of the stages of the cycle of the seminiferous epithelium in the rat. Ann. NY Acad. Sci., 55, 548-573.

25. Humetskyi, R.Ya., Palianytsia, B.M., \& Chaban, M.E. (2004). Matematychni metody $v$ biolohii [Mathematical methods in biology]. Lviv: Vyshcha shkola [in Ukrainian].

26. Kumar, R., \& Chaudhuri, B.N. (1989). Altered maternal thyroid function: fetal and neonatal development of rat. Indian J. Physiol. Pharmacol., 33 (4), 233-238.

\title{
ВЛИЯНИЕ ЭКСПЕРИМЕНТАЛЬНОГО ГИПЕРТИРЕОЗА МАТЕРИНСКОГО ОРГАНИЗМА НА ПОСТНАТАЛЬНЫЙ МОРФОГЕНЕЗ ЯИЧЕК ПОТОМСТВА ПО ДАННЫМ МОРФОМЕТРИИ И ЛЕКТИНОВОЙ ГИСТОХИМИИ
}

\author{
๑А. Ю. Шегедин, Х. И. Струс, А. М. Ященко \\ Львовский национальный медицинский университет имени Данила Галицкого
}

РЕЗЮМЕ. С использованием методов морфометрии и лектиновой гистохимии проведено исследование влияния экспериментального гипертиреоза материнского организма на структурные компоненты яичек потомства на последовательных этапах постнатального онтогенеза.

Цель - изучение влияния гипертиреоза материнского организма на микроморфологию и гликановый профиль яичек потомства.

Материал и методы. Гипертиреоз индуцировали путем ежедневного скармливания животным L-тироксина в дозе 100 мкг/кг за две недели до покрытия самок, на протяжении всего гестационного периода и лактации. Панель лектинов включала GNA, PNA, SBA, WGA, SNA и LABA.

Результаты. Установили, что под влиянием гипертиреоза материнского организма в яичках потомства на 20-е пренатальные и 1-е постнатальные сутки онтогенеза уменьшалось содержание интерстициальной соединительной ткани, в составе семенных тяжей повышалась пролиферативная активность клеток Сертоли. На 20 постнатальные сутки повышенная пролиферативная активность сперматогенного эпителия семенных трубочек сочеталась с редукцией рецепторов лектинов в сперматоцитах адлюменального компартмента. На 40 сутки постнатального развития у животных опытной группы выявлены ускорение биогенеза акросом, деструктивные изменения клеточных элементов с уменьшением диаметра семенных трубочек и соответствующим расширением интерстиция. Различия в связывании лектинов со структурными компонентами яичек крыс контрольной и опытной групп были максимально выражены на 20-е сутки пренатального онтогенеза и нивелировались у половозрелых животных, что свидетельствует о преходящем влиянии материнского гипертиреоза на гистофизиологию яичек потомства. В условиях материнского гипертиреоза имела место тенденция к редукции рецепторов лектинов в структурных компонентах яичек потомства, однако достоверных качественных различий в структуре их углеводных детерминант не выявлено. В проведенном исследовании лектины GNA и LABA интенсивно взаимодействовали с фетальными клетками Лейдига, лектины PNA, SBA и SNA - с акросомными гранулами и шапочками ранних сперматид, лектины WGA и PNA - с макрофагами в составе интерстиция яичек, что позволяет рекомендовать эти лектины в качестве селективных гистохимических маркеров указанных клеточных популяций.

Выводы. Полученные данные углубляют существующие представления о негативном влиянии гипертиреоза материнского организма на морфогенез и гистофизиологию яичек потомства, а также демонстрируют новые возможности использования лектинов в качестве селективных гистохимических маркеров структурных компонентов яичек крысы.

КЛЮЧЕВЫЕ СЛОВА: крысы; гипертиреоз материнского организма; морфогенез яичек потомства; морфометрия; лектиновая гистохимия. 
Огляди літератури, оригінальні дослідження, погляд на проблему, випадок з практики, короткі повідомлення

\title{
INFLUENCE OF MATERNAL HYPERTYROIDISM ON POSTNATAL MORPHOGENESIS OF PROGENY TESTES AS DETECTED BY MORPHOMETRIC AND LECTIN HISTOCHEMISTRY METHODS
}

\author{
๑A. Yu. Shegedin, Kh. I. Strus, A. M. Yashchenko \\ Danylo Halytskyi Lviv National Medical University
}

SUMMARY. By means of morphometric and lectin histochemistry methods the impact of maternal hyperthyroidism on the structural components of progeny testes on the successive stages of postnatal ontogeny was investigated.

The aim of the study - to invesigate the impact of maternal hyperthyroidism on the micromorphology and glycan profile of progeny testes.

Material and Methods. Hyperthyroidism was induced by feeding experimental group of animals with $100 \mathrm{mkg} / \mathrm{kg}$ of L-thyroxine for two weeks before pregnancy, throughout the gestational and lactation period. The lectin panel included GNA, PNA, SBA, WGA, SNA, and LABA.

Results. On the 20th prenatal and 1st postnatal days within the progeny testes maternal hyperthyroidism induced significant decrease of interstitial connective tissue content, which was accompanied by the enhanced proliferative activity of Sertoli cells of seminiferous cords. On postnatal day 20th increased proliferative rate of the spermatogenic epithelium was combined with reduction of lectin receptors sites in spermatocytes located within seminiferous tubules adulmenal compartment. On postnatal day 40th experimental group animals demonstrated acceleration of acrosomal biogenesis, destructive changes in cellular components of seminiferous tubules with diminution of their diameter and compensatory interstitial space expansion. Differences in morphometric parameters and lectin labeling of testicular components of control and experimental group rats were maximally expressed on the prenatal day 20 th with subsequent deminishing in sexually mature animals, indicating a transient impact of maternal hyperthyroidism on the histophysiology of progeny testes. A trend for reduction of lectin receptor sites in progeny testes under the influence of maternal hyperthyroidism has been noted, but no significant qualitative differences in their carbohydrate determinants were detected so far. In the present study it was documented intense labeling of fetal Leydig cells with GNA and LABA, of acrosomal granules and caps of early spermatids - with PNA, SBA, and SNA, of interstitial macrophages - with WGA and PNA lectins, which therefore can be recommended as selective histochemical markers of these cell populations.

Conclusions. The data presented expands the existing knowledge on the negative impact of maternal hyperthyroidism on morphogenesis and histophysiology of progeny testes, and demonstrate new possibilities of lectins application as selective histochemical markers of rat testicular components.

KEY WORDS: rats; maternal hyperthyroidism; progeny testes morphogenesis; morphometry; lectin histochemistry.

Отримано 22.08.2019 